\title{
PENGARUH PEMBELAJARAN KOOPERATIF DENGAN TEKNIK THINK-PAIR- SQUARE TERHADAP PENINGKATAN KEMAMPUAN PEMAHAMAN MATEMATIS SISWA
}

\author{
Lois Oinike Tambunan \\ Fakultas Keguruan dan Ilmu Pendidikan (FKIP) \\ Universitas HKBP Nommensen Pematangsiantar \\ e-mail :loistamb@gmail.com
}

\begin{abstract}
ABSTRAK
Penelitian ini bertujuan untuk mengetahui apakah peningkatan kemampuan pemahaman dan komunikasi matematis siswa yang mendapat pembelajaran kooperatif dengan teknik Think-PairSquare (TPS) lebih tinggi daripada siswa yang mendapat pembelajaran konvensional. Penelitian dilakukan dengan menggunakan metode eksperimen dan desain kelompok kontrol non-ekivalen. Populasi dalam penelitian ini adalah seluruh siswa kelas I SMA Swasta HKBP Pematangsiantar. Untuk memperoleh data yang diperlukan, digunakan instrumen berupa tes kemampuan pemahaman matematis, format observasi, dan angket untuk siswa. Analisis data dilakukan secara kuantitatif untuk data hasil pretes, postes, dan nilai gain, dan secara kualitatif untuk data hasil observasi, dan angket untuk siswa.Hasil penelitian menunjukkan bahwa: (a) Peningkatan kemampuan pemahaman matematis siswa yang mendapat pembelajaran kooperatif dengan teknik Think-Pair-Square (TPS) lebih tinggi daripada siswa yang mendapat pembelajaran konvensional; (b) Aktivitas siswa yang mendapat pembelajaran kooperatif dengan teknikThinkPair-Square(TPS) adalah baik; (c) Siswa menunjukkan sikap yang positif terhadap pembelajaran kooperatif dengan teknik Think-Pair-Square (TPS).
\end{abstract}

Kata Kunci: Pembelajaran Kooperatif Teknik Think-Pair-Square (TPS), Pemahaman dan Komunikasi Matematis.

\begin{abstract}
This research aims to determine whether the increase in mathematical understanding and communication skills of students who receive cooperative learning with Think-Pair-Square (TPS) techniques is higher than students who get conventional learning. The study was conducted using experimental methods and the design of a non-equivalent control group. The population in this study were all first grade students of SMA Swasta HKBP Pematangsiantar. To obtain the required data, instruments used in the form of tests of mathematical understanding ability, observation formats, and questionnaires for students. Data analysis was carried out quantitatively for the results of the pretest, posttest, and gain values, and qualitatively for the observational data, and the questionnaire for students. The results showed that: (a) Increased mathematical understanding ability of students who received cooperative learning with ThinkPair-Square (TPS) techniques was higher than students who received conventional learning; (b) The activities of students who get cooperative learning with Think-Pair-Square (TPS) techniques are good; (c) Students show a positive attitude towards cooperative learning with Think-PairSquare (TPS) techniques.

Key words :Cooperative Learning Think-Pair-Square (TPS) Techniques, Mathematical Understanding and Communication.
\end{abstract}




\section{Pendahuluan}

Dalam menghadapi abad ke-21 ini, bangsa Indonesia harus menyiapkan sumber daya manusia yang handal dan mampu berkompetisi secara global, yaitu manusia yang memiliki keterampilan berpikir kritis, sistematis, logis, kreatif, serta mampu bekerjasama. Hal ini disebabkan perkembangan ilmu dan teknologi dalam era ini berkembang dengan sangat pesatnya. Selain itu, proses globalisasi juga menuntut bangsa ini untuk berada dalam mega kompetisi, sehingga kompetisi akan menjadi prinsip hidup dalam dunia yang terbuka dan berkembang pesat (Tilaar, 1999).

Matematika adalah salah satu pelajaran yang termasuk dalam program adaptif, sehingga matematika mempunyai peranan dalam pengembangan diri siswa dan menunjang penguasaan keahlian profesi. Artinya, ketika siswa sudah berada di tengah masyarakat atau dunia kerja dan bermaksud mengembangkan potensi pada dirinya, kecakapan matematika yang ditumbuhkan pada siswa yang berkaitan dengan penalaran, komunikasi, dan pemecahan masalah dalam pembelajaran matematika akan sangat bermanfaat. Oleh karena itu, kemampuan matematika yang dipilih dalam standar kompetensi Kurikulum SMA dirancang sesuai dengan kebutuhan siswa agar mereka dapat berkembang secara optimal dan dapat beradaptasi dengan perkembangan zaman. Untuk mencapai kompetensi tersebut, materi-materi matematika dipilih dengan memperhatikan struktur keilmuan, tingkat kedalaman materi, serta sifat esensial materi dan keterpakaiannya dalam dunia kerja yang akan dimasukinya kelak dan kehidupan sehari-hari.

Selain materi yang dipilih, proses pembelajaran matematika di SMA juga diharapkan dapat membentuk sikap kritis, kreatif, jujur, sistematis, logis, dan komunikatif pada diri siswa. Dengan demikian, siswa diharapkan memiliki kemampuan memperoleh, memilih, dan mengelola informasi ketika siswa berada di tengah masyarakat atau lingkungan kerja.

Akan tetapi, kenyataan yang terjadi di lapangan menunjukkan bahwa hasil belajar siswa SMA pada pembelajaran matematika masih kurang optimal. Hal ini dapat diketahui melalui adanya penurunan kualitas tenaga pengajar, terutama dalam unsur kognitifnya (Santoso, 2000: 3).Temuan ini didukung oleh Rusgianto (2002: 1) yang mengatakan bahwa meskipun ada siswa yang memperoleh prestasi tinggi dalam matematika tetapi pada kenyataannya mereka tidak benar-benar mengerti tentang materi yang dipelajarinya. Ketika siswa dihadapkan pada suatu permasalahan seharihari, siswa belum mampu mengaplikasikan pengetahuan matematika yang dimilikinya untuk menyelesaikan permasalahan tersebut.

Temuan lain adalah dari hasil evaluasi TIMSS tahun 2003 yang menunjukkan bahwa skor rata-rata matematika siswa di Indonesia adalah 411 untuk tingkat SMP. Indonesia juga menduduki peringkat ke-34 dari 45 negara yang menjadi sampel TIMSS. Melihat kenyataan ini, tentunya sangat memprihatinkan bila dibandingkan dengan negara tetangga kita, seperti Singapura yang menduduki peringkat ke-1 dengan skor ratarata 605, dan Malaysia menduduki peringkat ke-10 dengan skor rata-rata 508 (Gonzales, 2004). Selain itu, Utari-Sumarmo (1987: 297) menemukan bahwa keadaan skor kemampuan siswa dalam pemahaman masih rendah dan siswa masih banyak mengalami kesukaran dalam pemahaman relasional. Wahyudin (1999) juga menemukan bahwa rata-rata tingkat penguasaan matematika siswa cenderung rendah. Walaupun hasil temuan ini bukan pada siswa SMA, tetapi dapat dijadikan gambaran umum mengenai 
hasil belajar matematika di tingkat pendidikan menengah.

Fakta di atas menunjukkan bahwa proses pembelajaran yang diterapkan saat ini belum menunjukkan hasil yang memuaskan. Sebagian besar guru sekolah menengah umum cenderung menggunakan model pembelajaran biasa atau konvensional, yaitu model pembelajaran yang lebih terfokus pada guru sedangkan siswanya cenderung pasif. Siswa lebih banyak menerima saja apa yang disampaikan oleh guru. Begitu pula dengan proses pembelajaran matematika di SMA, masih banyak guru yang menggunakan pembelajaran konvensional, sehingga siswa menjadi lebih pasif karena hanya dijadikan objek atau sasaran belajar, sedangkan guru sebagai pemberi informasi. Suasana kelas juga masih didominasi oleh guru dan masih menekankan pada latihan mengerjakan soal atau drill. Pembelajaran seperti ini membuat siswa menjadi kurang aktif dan kurang mengundang sikap kritis pada siswa.

Dalam fungsi, tujuan, dan aspek kemampuan yang ingin dicapai dalam Kurikulum Matematika SMA, disebutkan bahwa kemampuan pemahaman matematis merupakan hal yang sangat penting dan perlu ditingkatkan dalam pembelajaran matematika.. Hal ini mengakibatkan siswa akan mengalami kesulitan dalam memberikan penjelasan yang benar dan logis atas jawabannya. Ini sesuai dengan pendapat Cai, Lane, dan Jakabcsin (1996a) yang mengemukakan bahwa karena siswa jarang diminta untuk berargumentasi dalam pelajaran matematika, akibatnya sangat asing bagi mereka untuk berbicara tentang matematika. Selain itu, padatnya materi dalam kurikulum, menyebabkan guru hanya berkonsentrasi pada pencapaian penyelesaian materi, sehingga guru tak sempat lagi memikirkan bagaimana meningkatkan kemampuan pemahaman matematis siswanya.
Dari penjelasan di atas, jelaslah bahwa kemampuan pemahaman matematis merupakan hal yang sangat penting dan perlu ditingkatkan dalam pembelajaran matematika. Untuk itu, guru dalam memilih model pembelajaran perlu mempertimbangkan tugas matematika dan suasana belajar yang dapat memotivasi dan mendorong siswa untuk mencapai kemampuan tersebut.

Konsep-konsep dalam matematika terorganisasikan secara sistematis, logis, dan hirarkis dari yang paling sederhana ke yang paling kompleks. Dengan kata lain, pemahaman dan penguasaan suatu materi/konsep merupakan prasyarat untuk dapat menguasai materi/konsep selanjutnya. Oleh karena itu, dapatlah dimengerti bahwa kemampuan pemahaman matematis merupakan hal yang sangat fundamental dalam pembelajaran matematika agar belajar menjadi lebih bermakna.

Model pembelajaran yang diduga dapat meningkatkan kemampuan pemahaman matematis siswa adalah pembelajaran kooperatif. Dalam pembelajaran koperatif, siswa akan lebih aktif karena terjadi proses diskusi atau interaksi di antara siswa dalam kelompoknya. Melalui kegiatan diskusi, percakapan dalam mengungkapkan ide-ide matematika dapat membantu siswa mengembangkan pikirannya, sehingga siswa yang terlibat dalam perbedaan pendapat atau mencari solusi dari suatu permasalahan akan memahami konsep matematika dengan lebih baik dan dapat meningkatkan kemampuan pemahamanmatematisnya..Lie (2004) mengartikan pembelajaran kooperatif, yang disebutnya pembelajaran gotong royong, sebagai suatu sistem pengajaran yang memberi kesempatan kepada siswa untuk bekerja sama dengan siswa lain dalam menyelesaikan tugas-tugas yang terstruktur, sedangkan guru bertindak sebagai fasilitator. 
Salah satu teknik dalam pembelajaran kooperatif adalah Think-PairSquare (TPS). Teknik ini didesain untuk memberikan kesempatan kepada siswa untuk berpikir dan bekerja secara individual (think), berdiskusi dengan teman pasangan (pair), dan dilanjutkan dengan berdiskusi dengan pasangan lain dalam kelompok (square). Kagan (Maitland, 2001) menyarankan penggunaan teknik TPS ini dalam upaya meningkatkan kemampuan berpikir, komunikasi, dan mendorong siswa untuk berbagi informasi dengan siswa lain.

\section{Metode Penelitian}

Penelitian ini dilakukan di SMA Swasta HKBP Pematangsiantar. Penelitian ini dilakukan untuk mengetahui peningkatan kemampuan pemahaman matematis siswa yang mendapat pembelajaran kooperatif dengan teknik TPS. Untuk mengetahui pengaruh pembelajaran kooperatif dengan teknik TPS terhadap peningkatan kemampuan pemahaman matematis siswa, diperlukan kelas lain yang menggunakan model pembelajaran lama atau yang biasa dilakukan sehari-hari sebagai pembanding. Sebagaimana diungkapkan oleh Furchan (2005, 358), Sukmadinata (2005: 58), Gullo (2002: 20), dan Ruseffendi (2003: 45) bahwa dalam suatu penelitian eksperimen, khususnya penelitian yang ingin menyelidiki keefektifan penggunaan metode mengajar baru, diperlukan kelas lain atau kelompok siswa yang menggunakan metode lama atau yang biasa dilakukan sebelumnya sebagai pembanding. Kelas pembanding ini disebut kelas kontrol. Hasil dari kelas kontrol ini akan menjadi pembanding dari kelas eksperimen untuk mengetahui apakah hasil kelas eksperimen lebih tinggi daripada kelas kontrol.

Jadi, dalam penelitian ini terdapat dua kelas, yaitu kelas eksperimen dan kelas kontrol. Kelas yang mendapat perlakuan pembelajaran kooperatif dengan teknik TPS disebut kelas eksperimen, dan kelas pembanding yang menggunakan pembelajaran yang biasa dilakukan seharihari atau pembelajaran konvensional disebut kelas kontrol.

Untuk mengetahui besarnya peningkatan kemampuan pemahaman matematis siswa, pada kedua kelas tersebut dilakukan pretes dan postes. Pretes diberikan sebelum proses pembelajaran dalam penelitian ini dimulai, sedangkan postes setelah keseluruhan proses pembelajaran selesai.

Dengan demikian, desain penelitian yang digunakan dalam penelitian ini adalah desain yang melibatkan dua kelompok dengan pretes dan postes. Pengambilan kelompok tidak dilakukan secara acak. Desain ini disebut desain kelompok kontrol non-ekivalen (Ruseffendi, 2003: 47).

\section{Hasil Penelitian}

Data yang diperoleh dan dianalisis dalam penelitian ini adalah hasil tes kemampuan pemahaman, hasil observasi selama proses pembelajaran di kelas eksperimen, dan angket untuk siswa.

Hasil tes kemampuan pemahaman matematis memberikan informasi tentang kemampuan siswa sebelum dan sesudah dilakukan proses pembelajaran, baik di kelas eksperimen maupun kelas kontrol. Informasi tersebut berupa data hasil pretes, postes, dan gain ternormalisasi. Hasil tes kemampuan pemahaman matematis memberikan informasi tentang kemampuan siswa sebelum dan sesudah dilakukan proses pembelajaran, baik di kelas eksperimen maupun kelas kontrol. Informasi tersebut berupa data hasil pretes, postes, dan gain ternormalisasi. Untuk kemampuan pemahaman matematis, rata-rata skor kelas eksperimen (6,719) sedikit lebih besar daripada kelas kontrol (6,125). Jika dibandingkan dengan skor ideal (20), maka rata-rata skor kelas eksperimen adalah $33,59 \%$ dari skor ideal, sedangkan kelas kontrol adalah 30,62\% dari skor ideal. Akan 
tetapi, deviasi standar kelas kontrol $(2,366)$ terlihat lebih besar daripada kelas eksperimen (2,218). Hal ini menunjukkan bahwa kemampuan pemahaman matematis siswa kelas kontrol lebih menyebar daripada kelas eksperimen.

Namun, untuk mengetahui benar tidaknya anggapan tersebut perlu dilakukan uji perbedaan dua rata-rata. Sebelum menentukan tes statistik yang akan digunakan, terlebih dahulu perlu dilakukan uji normalitas dan homogenitas (Sudjana, 2003). Setelah mengetahui bahwa data pretes kemampuan pemahaman dan komunikasi matematis siswa kelas eksperimen dan kontrol berasal dari populasi yang berdistribusi normal dan memiliki variansi yang homogen, maka tes statistik yang akan digunakan untuk pengujian perbedaan dua rata-rata adalah uji- $t$.

Perhitungan uji perbedaan dua ratarata data pretes kelas eksperimen dan control menunjukkan bahwa nilai $t_{\text {hitung }}$ kemampuan pemahaman matematis sebesar 1,037 memenuhi kriteria $-t_{\text {tabel }}<t_{\text {hitung }}<t_{\text {tabel }}$ pada taraf signifikansi $\alpha=0,05$ sehingga $\mathrm{H}_{0}$ diterima. Ini berarti bahwa rata-rata skor pretes kemampuan pemahaman matematis siswa kelas eksperimen tidak berbeda dengan kelas kontrol. Dengan demikian dapat disimpulkan bahwa berdasarkan hasil uji perbedaan dua rata-rata, skor pretes kemampuan pemahaman matematis siswa kelas eksperimen tidak berbeda dengan kelas kontrol. Dengan kata lain, kemampuan pemahaman dan komunikasi matematis siswa kelas eksperimen dan kontrol sebelum memperoleh pembelajaran adalah sama.Hasil postes dianalisis dengan tujuan untuk mengetahui kemampuan pemahaman dan komunikasi matematis siswa setelah keseluruhan proses pembelajaran dalam penelitian ini selesai, baik di kelas eksperimen maupun di kelas kontrol. Hasil postes memperlihatkan bahwa skor maksimal kemampuan pemahaman matematis siswa kelas eksperimen (18) lebih tinggi daripada kelas kontrol (15). Tabel ini juga memberi gambaran bahwa nilai ratarata postes kemampuan pemahaman matematis siswa kelas eksperimen lebih tinggi daripada kelas kontrol. Rata-rata skor kelas eksperimen adalah 13,000 sedangkan kelas kontrol adalah 10,250 dari skor ideal 20, dan perbedaan rata-rata di antara keduanya adalah $21,15 \%$ terhadap rata-rata skor kelas eksperimen. Jika dibandingkan dengan skor ideal, maka rata-rata skor kelas eksperimen adalah $65,00 \%$ dari skor ideal sedangkan kelas kontrol adalah 51,25\% dari skor ideal. Kemampuan pemahaman matematis siswa kelas eksperimen juga lebih menyebar daripada kelas kontrol. Hal ini dapat dilihat dari deviasi standar kelas eksperimen $(2,514)$ yang lebih besar daripada kelas kontrol (2,258). Untuk melihat signifikan tidaknya perbedaan tersebut, maka perlu dilakukan uji perbedaan dua rata-rata. Namun sebelumnya, dilakukan uji normalitas dan homogenitas untuk menentukan tes statistik yang akan digunakan (Sudjana, 2003).Hasil menunjukkan bahwa nilai $t_{\text {hitung }}$ kemampuan pemahaman matematis sebesar 4,606 tidak memenuhi kriteria $-t_{\text {tabel }}<t_{\text {hitung }}<t_{\text {tabel }}$ pada taraf signifikansi $\alpha=0,05$ sehingga $\mathrm{H}_{0}$ ditolak. Ini berarti bahwa rata-rata skor postes kemampuan pemahaman matematis siswa kelas eksperimen lebih tinggi daripada kelas kontrol.

Untuk mengetahui apakah peningkatan kemampuan pemahaman dan komunikasi matematis siswa yang mendapat pembelajaran kooperatif dengan teknik TPS lebih tinggi daripada siswa yang mendapat pembelajaran konvensional, maka terlebih dahulu dihitung nilai gain setiap siswa. Dalam hal ini, perhitungan gain menggunakan gain ternormalisasi dengan tujuan agar perbedaanpeningkatan setiap siswa dapat terlihat. 
adalah $\begin{gathered}\text { Hipotesis ke-1 dalam penelitian ini } \\ \text { "Peningkatan kemampuan }\end{gathered}$ pemahaman matematis siswa yang mendapat pembelajaran kooperatif dengan teknik TPS lebih tinggi daripada siswa yang mendapat pembelajaran konvensional". Berdasarkan hipotesis penelitian yang diajukan tersebut, maka hipotesis nol $\left(\mathrm{H}_{0}\right)$ yang diuji adalah "Peningkatan kemampuan pemahaman matematis siswa yang mendapat pembelajaran kooperatif dengan teknik TPS sama dengan siswa yang mendapat pembelajaran konvensional". Dengan demikian, rumusan hipotesis statistiknya adalah sebagai berikut:

$$
\begin{aligned}
& \mathrm{H}_{0}: \mu_{e}=\mu_{k} \\
& \mathrm{H}_{1}: \mu_{e}>\mu_{k} \\
& \mu_{e}=\text { rata-rata gain kemampuan }
\end{aligned}
$$
pemahaman matematis kelas eksperimen.

$$
\mu_{k}=\text { rata-rata gain kemampuan }
$$

pemahaman matematis kelas kontrol. Terlihat bahwa nilai $t_{\text {hitung }}$ tidak memenuhi kriteria $-t_{\text {tabel }}<t_{\text {hitung }}<t_{\text {tabel }}$ pada taraf signifikansi $\alpha=0,05$ sehingga $\mathrm{H}_{0}$ ditolak. Hal ini menunjukkan bahwa rata-rata gain kemampuan pemahaman matematis siswa kelas eksperimen lebih besar daripada kelas kontrol. Dengan kata lain, peningkatan kemampuan pemahaman matematis siswa yang mendapat pembelajaran kooperatif dengan teknik TPS lebih tinggi daripada siswa yang mendapat pembelajaran konvensional.

Sikap siswa terhadap pembelajaran matematika yang dianalisis yaitu tanggapan siswa terhadap pelajaran matematika di sekolah (pernyataan nomor 1, 2 dan 3) dan tanggapan siswa terhadap cara guru mengajar matematika (pernyataan nomor 4 dan 5). Dari hasil interpretasi pernyataan tentang tanggapan siswa terhadap pembelajaran matematika di sekolah, dapat disimpulkan bahwa sebagian besar siswa memiliki sikap yang positif terhadap pelajaran matematika. Sedangkan dari hasil interpretasi pernyataan tentang tanggapan siswa terhadap cara guru mengajar matematika, didapat kesimpulan bahwa cara guru mengajar dapat membuat siswa lebih mudah memahami materi dan mengerjakan soal-soal matematika.

Sikap siswa terhadap pembelajaran kooperatif dengan teknik TPS yang dianalisis adalah tanggapan siswa terhadap pembelajaran kooperatif dengan teknik TPS (pernyataan nomor 6 sampai 12) dan tanggapan siswa terhadap peran guru dalam pembelajaran kooperatif dengan teknik TPS (pernyataan nomor 13 dan 14).

Sikap siswa secara keseluruhan terhadap soal-soal pemahaman matematis adalah positif. Hal ini dapat dilihat dari skor sikap siswa $(3,32)$ yang lebih besar daripada skor netral $(2,75)$. Ini artinya siswa lebih banyak menunjukkan sikap positifnya terhadap soalsoal pemahaman matematis daripada menunjukkan sikap netralnya, sehingga ratarata skor sikapnya lebih besar daripada skor netral.

Sikap positif ini juga dapat dilihat dari penyebaran jawaban siswa. Dari pernyataan nomor 15 (soal-soal yang diberikan guru sangat membantu saya mengembangkan kemampuan menggambar, membuat model matematika, dan menjelaskan dengan bahasa sendiri) sebanyak 28 siswa menyatakan setuju dan sangat setuju dengan pernyataan ini, dan hanya 4 siswa yang tidak setuju dan sangat tidak setuju. Untuk pernyataan nomor 20 (soal-soal matematika yang diberikan guru dapat melatih kemampuan saya untuk mengaplikasikan konsep-konsep dalam bidang studi kejuruan atau pelajaran lain) sebanyak 30 siswa menyatakan setuju dan sangat setuju, sedangkan 2 siswa menyatakan tidak setuju dan sangat tidak setuju. Kemudian untuk pernyataan nomor 21 (soal-soal yang diberikan guru tidak bermanfaat bagi kehidupan sehari-hari, dunia kerja, dan bidang studi kejuruan saya) 
sebanyak 29 siswa menyatakan tidak setuju dan sangat tidak setuju sedangkan 3 siswa menyatakan setuju dan sangat setuju.

Dari hasil interpretasi pernyataanpernyataan di atas, dapat disimpulkan bahwa sebagian besar siswa menunjukkan sikap positif terhadap soal-soal pemahaman matematis yang diberikan.

\section{Pembahasan}

Pemahaman merupakan terjemahan dari understanding (Utari-Sumarmo, 1987). Definisi lain dikemukakan oleh Gilbert (Rahman, 2004), bahwa pemahaman adalah kemampuan menjelaskan suatu situasi dengan kata-kata yang berbeda dan dapat menginterpretasikan atau menarik kesimpulan dari tabel, data, grafik, dan sebagainya.

Pengetahuan dan pemahaman siswa terhadap konsep matematika, menurut NCTM (1989: 223) dapat dilihat dari kemampuan siswa dalam: mendefinisikan konsep secara verbal dan tulisan; (2) mengidentifikasi dan membuat contoh dan bukan contoh; (3) menggunakan model, diagram, dan simbol-simbol untuk mempresentasikan suatu konsep; (4) mengubah suatu bentuk representasi ke bentuk lainnya; (5) mengenal berbagai makna dan interpretasi konsep; (6) mengidentifikasi sifat suatu konsep dan mengenal syarat yang menentukan suatu konsep; dan (7) membandingkan dan membedakan konsep-konsep.

Polya (Utari-Sumarmo, 2005) mengemukakan empat tingkat pemahaman suatu hukum, yaitu pemahaman mekanikal, pemahaman induktif, pemahaman rasional, dan pemahaman intuitif. Pemahaman mekanikal, apabila siswa dapat mengingat dan menerapkan rumus secara rutin dan menghitung secara sederhana. Pemahaman induktif, apabila siswa dapat menerapkan rumus atau konsep dalam kasus sederhana atau dalam kasus serupa. Pemahaman rasional, apabila siswa dapat membuktikan kebenaran suatu rumus dan teorema. Pemahaman intuitif, apabila siswa dapat memperkirakan kebenaran dengan pasti sebelum menganalisis lebih lanjut.

Menurut Skemp (Utari-Sumarmo, 2005), pemahaman digolongkan menjadi dua jenis, yaitu pemahaman instrumental dan pemahaman relasional. Pemahaman intrumental adalah pemahaman atas konsep/prinsip tanpa kaitan dengan yang lainnya dan dapat menerapkan rumus dalam perhitungan sederhana. Pada pemahaman relasional, termuat suatu skema atau struktur yang dapat digunakan pada penyelesaian masalah yang lebih luas dan dapat mengaitkan suatu konsep/prinsip dengan konsep/prinsip lainnya.

Suherman dkk. (2003: 263) mengemukakan bahwa guru memainkan peranan penting agar model pembelajaran ini berhasil dengan baik. Materi, masalah, atau tugas yang diberikan kepada siswa harus disusun sedemikian rupa sehingga setiap siswa dapat menyumbangkan ide kepada kelompoknya dan menimbulkan rasa saling membutuhkan antara anggota yang satu dengan yang lain. Selain itu, guru juga harus memiliki pemahaman yang baik tentang pembelajaran kooperatif dan memberikan pengarahan kepada siswa ketika akan melaksanakan model pembelajaran ini.

Menurut Ibrahim dkk. (2000), model pembelajaran kooperatif dikembangkan untuk mencapai setidak-tidaknya tiga tujuan penting dalam pembelajaran, yaitu:

1. Meningkatkan hasil belajar akademik Model pembelajaran kooperatif bertujuan untuk meningkatkan kinerja siswa dalam tugas-tugas akademik dan membantu siswa memahami konsep-konsep yang sulit, sehingga prestasi siswa yang belajar dalam kelompok kooperatif lebih baik daripada mereka yang belajar secara individual. Selain itu, 
pembelajaran kooperatif juga dapat memberikan keuntungan bagi siswa kurang pandai maupun siswa pandai. Bagi siswa yang kurang pandai, akan lebih termotivasi untuk belajar karena mereka tahu bahwa tujuan mereka dapat tercapai jika mereka bersama-sama mencapai tujuan tersebut, dan bagi siswa pandai akan menjadi tutor bagi siswa kurang pandai. Proses tutorial ini, selain dapat meningkatkan pemahaman suatu konsep siswa pandai juga dapat meningkatkan kemampuan komunikasi verbal dan kemampuan akademiknya karena menjadi tutor membutuhkan ide-ide yang lebih mendalam tentang suatu materi.

2. Penerimaan terhadap perbedaan individual

Pembelajaran kooperatif memberi peluang kepada siswa yang berbeda latar belakang dan kondisi untuk belajar saling bergantung atas tugastugas bersama dan saling menghargai. Pembentukan kelompok yang heterogen, akan memberikan kesempatan kepada siswa untuk saling menerima, saling mengajar, saling mendukung, dan meningkatkan relasi dan interaksi antaragama, budaya, dan gender.

3. Pengembangan keterampilan sosial Tujuan penting yang ketiga dari pembelajaran kooperatif adalah untuk mengajarkan kepada siswa ketrampilan bekerja sama dan kolaborasi. Ketrampilan ini penting untuk dimiliki siswa ketika berada di dalam masyarakat dengan budaya yang semakin beragam, atau dunia kerja yang sebagian besar dilakukan dalam organisasi yang saling bergantung satu sama lain.

Johnson dan Johnson (Lie, 2004) mengemukakan lima unsur pembelajaran kooperatif agar dapat mencapai hasil yang maksimal, yaitu:

1. Saling ketergantungan yang positif Setiap anggota kelompok harus memiliki perasaan bahwa keberhasilan individu merupakan keberhasilan bagi kelompoknya dan begitu pula sebaliknya. Hal ini menuntut guru untuk dapat menciptakan suasana belajar yang dapat mendorong siswa saling membutuhkan dan bergantung satu sama lain di dalam kelompoknya.

2. Tanggung jawab perseorangan Setiap anggota kelompok diberi tanggung jawab secara individual untuk mengerjakan bagian tugasnya sendiri, mengetahui apa yang harus dipelajari, dan mengetahui apa yang ditargetkan kelompoknya. Ini bertujuan agar setiap individu merasa dituntut untuk memberikan andil bagi keberhasilan kelompok dan merasa bertanggung jawab untuk melakukan yang terbaik.

3. Tatap muka

Setiap anggota kelompok harus diberi kesempatan untuk bertemu muka dan berdiskusi. Dengan interaksi tatap muka, siswa dapat melakukan dialog, dan menghargai perbedaan dengan memanfaatkan kelebihan dan mengisi kekurangan anggotanya.

4. Komunikasi antaranggota

Unsur ini menghendaki siswa memiliki kemampuan berinteraksi, seperti mengajukan pendapat, mendengarkan opini teman, dan mengadakan kompromi, negoisasi, atau klarifikasi. Untuk dapat memiliki kemampuan ini, diperlukan proses yang panjang. Namun, proses ini merupakan proses yang sangat bermanfaat dan perlu ditempuh untuk memperkaya pengalaman 
belajar dan pembinaan perkembangan mental dan emosional siswa.

5. Evaluasi proses kelompok

Guru perlu menjadwalkan waktu khusus bagi kelompok untuk mengevaluasi proses kerja kelompok dan hasil kerja sama mereka agar selanjutnya bisa bekerja sama dengan lebih efektif.

Berdasarkan uraian mengenai pembelajaran kooperatif, uraian mengenai proses atau kegiatan yang terjadi dalam belajar kooperatif, dan uraian tentang kelebihan yang diperoleh dengan belajar kooperatif, maka diharapkan bahwa pembelajaran kooperatif dapat meningkatkan kemampuan pemahaman dan komunikasi matematis siswa.

Berdasarkan uraian tentang pembelajaran kooperatif, dapat diketahui bahwa banyak keuntungan yang diperoleh dari model pembelajaran ini. Namun, tidak semua belajar dalam kelompok bisa dianggap sebagai belajar kooperatif. Siswa yang duduk berkelompok tetapi mengerjakan tugasnya secara individu, atau menugaskan seseorang dalam kelompok untuk menyelesaikan seluruh tugas kelompok, tidak dapat dikatakan sebagai belajar kooperatif.

Salah satu teknik dalam pembelajaran kooperatif adalah Think-PairSquare (TPS). Teknik ini didesain untuk memberikan kesempatan kepada siswa untuk berpikir dan bekerja secara individual (think), berdiskusi dengan teman pasangan (pair), dan dilanjutkan dengan berdiskusi dengan pasangan lain dalam kelompok (square).

Pembelajaran kooperatif dengan teknik Think-Pair-Square (TPS) merupakan modifikasi dari teknik think-pair-share, dan dikembangkan oleh Spencer Kagan pada tahun 1993. Kagan (Maitland, 2001) menyarankan penggunaan teknik TPS ini untuk meningkatkan kemampuan berpikir, komunikasi, dan mendorong siswa untuk berbagi informasi dengan siswa lain.

Berbeda dengan teknik think-pairshare, dalam teknik TPS guru membagi siswa dalam kelompok heterogen yang beranggotakan empat orang. Sebagai kegiatan awal adalah think atau tahap berpikir, yaitu sebelum bekerjasama dan berdiskusi dengan kelompoknya, setiap siswa diberi kesempatan untuk membaca, memahami, memikirkan kemungkinan jawaban, dan membuat catatan tentang halhal yang tidak dipahami atau informasi yang berhubungan dengan tugas. Kegiatan ini bertujuan agar setiap siswa dapat memberikan respon terhadap ide-ide yang terdapat pada LKS, untuk kemudian diterjemahkan ke dalam bahasa sendiri.

Setelah tahap think selesai, dilanjutkan dengan pair, atau tahap berpasangan. Pada tahap ini, siswa diminta untuk berpasangan dengan salah seorang teman dalam kelompoknya untuk mendiskusikan kemungkinan jawaban atau hal-hal yang telah ditulis dalam catatan pada waktu tahap think. Dengan berpasangan, partisipasi aktif siswa dalam kelompok dapat lebih dioptimalisasikan sehingga kemampuan pemahaman dan komunikasi matematis siswa dapat lebih ditingkatkan.

Pada saat berpasangan, siswa akan belajar untuk mengerti bahwa setiap orang dapat memiliki jawaban yang berbeda dengan alasannya sendiri. Siswa juga dapat mencoba semua kemungkinan secara berbeda dengan pasangannya, dan menyaring kembali, kemudian memformulasikan jawaban berdasarkan hasil diskusi. Dalam kegiatan ini, setiap siswa akan menggunakan bahasa dan katakata mereka sendiri untuk menyampaikan ide-ide matematikanya.

Setelah pasangan siswa berdiskusi, kemudian pasangan ini bergabung dengan pasangan lain dalam kelompoknya untuk 
membentuk kelompok berempat (square). Kedua pasangan ini mendiskusikan tugastugas yang belum dapat diselesaikan atau hal-hal yang belum dipahami ketika diskusi dengan pasangan, dan menetapkan hasil akhir jawaban kelompoknya. Pada tahap ini, siswa saling memberikan ide atau informasi yang mereka ketahui tentang soal yang diberikan untuk memperoleh kesepakatan dari penyelesaian soal tersebut.

Dengan adanya tahap pair dan square, terjadi lebih banyak diskusi sehingga dapat lebih meningkatkan dan mengoptimalisasikan partisipasi aktif siswa dalam kelompok. Selain itu, siswa juga akan memiliki lebih banyak kesempatan untuk berkontribusi dalam kelompoknya, dan interaksi antara siswa juga menjadi lebih mudah (Lie, 2004). Jadi, diharapkan tidak ada lagi siswa yang tidak aktif dalam kelompoknya.

Teknik Think-Pair-Square memiliki kelebihan dan kekurangan dalam pengimplementasiannya. Kelebihan kelebihan pembelajaran kooperatif dengan teknik TPS ini, diantaranya adalah :

1. Merupakan teknik yang paling sederhana dalam pembelajaran kooperatif dan mudah dilaksanakan dalam kelas, sehingga model pembelajaran ini dapat dilakukan secara mendadak dan mudah digunakan dalam kelas dengan jumlah siswa yang banyak (Instructional Strategies Online, 2005).

2. Dengan anggota kelompok berempat, guru akan lebih mudah memonitor dan mudah dipecah menjadi berpasangan, dan lebih banyak tugas yang dapat dilakukan (Lie, 2004).

3. Lebih banyak terjadi percakapan atau diskusi, baik pada waktu berpasangan maupun dalam kelompok berempat, sehingga akan lebih banyak ide muncul.
4. Optimalisasi partisipasi siswa dan memberi kesempatan kepada siswa untuk dikenali dan menunjukkan partisipasi mereka kepada orang lain.

5. Siswa diberi kesempatan untuk berdiskusi dan berpasangan dengan siswa yang lebih pintar atau lemah, daripada cara klasikal yang hanya satu orang atau beberapa orang saja yang berbicara.

6. Kegiatan guru dalam proses belajar mengajar semakin berkurang. Guru hanya berperan sebagai fasilitator yang mengarahkan dan memotivasi siswa untuk belajar mandiri serta menumbuhkan rasa tanggung jawab.

Pembelajaran kooperatif dengan teknik TPS ini juga memiliki kekurangan, yaitu membutuhkan pengaturan waktu dan sosialisasi yang baik, serta dapat menyulitkan proses pengambilan suara (Lie, 2004). Untuk mengatasi kekurangan tersebut, maka hal-hal yang harus diperhatikan adalah:

1. Guru harus pandai mengatur waktu yang tersedia seefisien mungkin sesuai dengan tingkat kesulitan materi.

2. Meminta siswa untuk terlebih dahulu mempelajari materi di rumah.

3. Guru harus dapat mensosialisasikan dengan baik tentang manfaat, tujuan, keuntungan yang diperoleh, dan tahap-tahap yang harus dilalui, agar siswa memahami dan tertarik untuk melakukan proses pembelajaran dengan teknik TPS ini.

Berdasarkan uraian tentang kegiatan atau tahapan-tahapan yang harus dilalui siswa ketika melaksanakan pembelajaran kooperatif dengan teknik TPS, langkah pembelajarannya, dan kelebihankelebihannya, maka diharapkan bahwa pembelajaran kooperatif dengan teknik think-pair-square dapat meningkatkan 
kemampuan pemahaman dan komunikasi matematis siswa.

Teori belajar yang mendasari pembelajaran kooperatif dengan teknik TPS adalah teori belajar yang berpandangan konstruktivisme. Pandangan ini menekankan peran aktif siswa dalam membangun pengetahuannya.

Teori belajar konstruktivisme dari Piaget mengatakan bahwa pengetahuan seseorang terbentuk berdasarkan keaktifan orang itu sendiri dalam berhadapan dengan persoalan, bahan atau lingkungan baru. Hal ini berarti orang itu sendirilah yang aktif membentuk pengetahuannya.

Konstruktivisme menurut Piaget ini disebut konstruktivisme personal karena lebih menekankan keaktifan seseorang secara individu dalam mengkonstruksi pengetahuannya

Menurut Piaget (Suparno, 2001) pengetahuan tidak diberikan dalam bentuk jadi, tetapi siswa membentuk pengetahuannya sendiri melalui proses asimilasi dan akomodasi. Proses asimilasi terjadi apabila struktur pengetahuan baru dibentuk berdasarkan pengetahuan yang sudah ada. Proses akomodasi merupakan proses menerima pengalaman baru yang tidak sesuai dengan pengetahuan lama sehingga terjadi ketidakseimbangan (disequilibrium). Untuk mencapai keseimbangan (equilibrium), struktur pengetahuan lama dimodifikasi dan menyesuaikan dengan pengetahuan baru tersebut.

Selain Piaget, konstruktivis lainnya adalah Vygotsky. Teori belajar Vygotsky mengatakan bahwa belajar dilakukan oleh seseorang ketika berinteraksi dengan lingkungan sosial maupun fisiknya, atau dengan kata lain perkembangan intelektual anak dipengaruhi oleh faktor sosial. Konstruktivisme menurut Vygotsky ini disebut pula sebagai konstruktivisme sosial. Slavin (1995: 17) mengatakan bahwa proses belajar menurut pandangan konstruktivisme sosial Vygotsky ini ditekankan pada hakekat sosiokultural dari pembelajaran itu sendiri. Suparno (2001) juga mengatakan bahwa Vygotsky lebih memfokuskan perhatiannya pada hubungan dialektik antara individu dan masyarakat dalam pembentukan pengetahuan.

Dari kedua pendapat tentang konstruktivisme, dapat dikatakan bahwa teori konstruktivisme menegaskan bahwa pengetahuan tidak dapat dipindahkan begitu saja dari pikiran guru kepada pikiran siswa, tetapi siswa aktif membentuk sendiri pengetahuannya. Namun, ada perbedaan antara pandangan antara Piaget dan Vygotsky. Menurut Piaget pengetahuan baru dibentuk melalui konstruksi seseorang yang sedang berpikir secara individu, sedangkan menurut Vygotsky pengetahuan baru dibentuk melalui konstruksi pribadi yang berinteraksi dengan lingkungannya.

Berdasarkan uraian mengenai teori belajar konstruktivisme dari Piaget dan Vygotsky, maka ciri-ciri pembelajaran yang berbasis pada konstruktivisme sangat sesuai dengan pembelajaran kooperatif dengan teknik TPS yang akan diterapkan pada penelitian ini. Dalam pembelajaran ini, diawali dengan siswa secara individu mengkonstruksi pengetahuannya melalui kegiatan think (berpikir), dilanjutkan dengan kegiatan berdiskusi dengan teman pasangannya melalui kegiatan pair (berpasangan) dan dengan pasangan lain dalam kelompoknya melalui kegiatan square(berempat),kemudian

merepresentasikan hasil pembentukan konsep atau pengetahuan ke seluruh kelas.

Pembelajaran konvensional dalam penelitian ini adalah pembelajaran yang biasa dilakukan oleh guru sehari-hari, yaitu secara tradisional atau klasikal. Proses pembelajaran diawali dengan guru menjelaskan materi pelajaran di depan kelas, dilanjutkan dengan memberi contoh soal dan 
cara menyelesaikannya, sedangkan siswa memperhatikan dan mencatat materi yang disampaikan oleh guru. Kemudian guru memberi kesempatan kepada siswa untuk menanyakan hal-hal yang belum dimengerti. Setelah itu guru memberi soal untuk dikerjakan siswa sebagai latihan (drill).

Dalam pembelajaran ini, guru pada umumnya mendominasi kelas dan lebih banyak menggunakan bentuk komunikasi searah dari guru kepada siswa, sedangkan siswa jarang sekali bertanya atau mengemukakan pendapatnya walaupun sudah diberi kesempatan. Menurut Ruseffendi (1991: 350) siswa dalam kelas ini memiliki kemampuan pada syarat minimal untuk tingkat itu. Minat, kepentingan, kecakapan, dan kecepatan belajar siswa diasumsikan relatif sama.

\section{Simpulan}

Berdasarkan hasil penelitian dan analisis data, diperoleh kesimpulan sebagai berikut:

1. Peningkatan kemampuan pemahaman matematis siswa yang mendapat pembelajaran dengan teknik TPS lebih tinggi daripada siswa yang mendapat pembelajaran konvensional.

2. Aktivitas siswa yang memperoleh pembelajaran kooperatif dengan teknik TPS adalah baik.

3. Siswa menunjukkan sikap yang positif terhadap pelaksanaan pembelajaran kooperatif dengan teknik TPS.

\section{Daftar Pustaka}

Ansari, B.I. (2004). Menumbuhkembangkan Kemampuan Pemahaman dan Komunikasi Matematis Siswa SMU melalui Strategi Think-Talk-Write. Disertasi Doktor pada PPS UPI Bandung: tidak dipublikasikan.

Cai, J., Lane, S., dan Jakabcsin, M.S. (1996b). "The Role of Open-Ended
Task and Holistic Scoring Rubrics: Assessing Students Mathematical Reasoning and Communication". Dalam Communication in Mathematics K-12 and Beyond, 1996 Year Book. National Council of Teachers of Mathematics.

Dahlan, J.A. (2004). Meningkatkan Kemampuan Penalaran dan Pemahaman Matematika Siswa Sekolah Lanjutan Tingkat Pertama melalui Pendekatan Pembelajaran Open-Ended. Disertasi Doktor pada PPS UPI Bandung: tidak dipublikasikan.

Departemen Pendidikan Nasional. (2001). Kamus Bsar Bahasa Indonesia Edisi Ketiga. Jakarta: Balai Pustaka.

Dinas Pendidikan Propinsi Jawa Barat. (2004). Pelajaran Matematika untuk SMK Kelas 1. Bandung: CV Andira.

Furchan, A. (2005). Pengantar Penelitian dalam Pendidikan. Yogyakarta: Pustaka Pelajar.

Gullo, W. (2002). Metodologi Penelitian. Jakarta: Gramedia.

Ibrahim, M., et al. (2000). Pembelajaran Kooperatif. Pusat Sains dan Matematika Sekolah Program Pascasarjana UNESA: University Press.

Lie, A. (2004). Cooperative Learning. Jakarta: Grasindo.

National Council of Teachers of Mathematics. (2000). Principles and Standards for School Mathematics. Reston, VA: NCTM.

Paul Suparno. 2001. Teori perkembangan kognitif Jean Piaget. Yogyakarta: Kanisius.

Ruseffendi, H.E.T. (1998). Statistika Dasar untuk Penelitian Pendidikan. Bandung: IKIP Bandung Press

Rusgianto. (2002). Contextual Teaching and Learning. Disajikan dalam Seminar 
Pendidikan Matematika 3 November 2002. FMIPA UNY: tidak diterbitkan.

Santoso, Z. (2000). Struktur dan Pola

Pembelajaran Mekanika di Sekolah

Kejuruan dengan Model Pengajaran

Konstruktivisme. Thesis pada PPS UPI

Bandung: tidak dipublikasikan.

Slavin, R.E. (1995). Cooperative Learning. USA: Allyn and Bacon.

Sudjana. (2005). Metode Statistika. Bandung: Tarsito.

Sugiyono. (2001). Statistika untuk Penelitian. Bandung: Alfabeta.

Suherman, E. dan Kusumah, Y.S. (1990). Petunjuk Praktis untuk Melaksanakan Evaluasi Pendidikan Matematika. Bandung: Wijayakusumah 157.

Suherman, E., et al. (2003). Strategi Pembelajaran

Matematika
Kontemporer. Bandung: FPMIPAJICA UPI Bandung.

Sukmadinata, N.S. (2005). Metode Penelitian Pendidikan, Bandung: Remaja Rosdakarya.

Utari-Sumarmo. (2005). "Pembelajaran Matematika untuk Mendukung Pelaksanaan Kurikulum Tahun 2002 Sekolah Menengah". Makalah pada Seminar Pendidikan Matematika di FPMIPA Universitas Negeri Gorontalo.

Wahyudin. (1999). Kemampuan Guru Matematika, Calon Guru Matematika, dan Siswa dalam Pelajaran Matematika. Disertasi Doktor pada PPS UPI Bandung: tidak dipublikasikan. 